\title{
Peranan Persepsi Bauran Pemasaran terhadap Keputusan Pembelian dan Loyalitas Produk Hatten Wines
}

\author{
IDA AYU PUTU CITRA DEWI, I GUSTI AYU OKA SURYAWARDANI, \\ PUTU UDAYANI WIJAYANTI
}

\author{
Jl. PB. Sudirman Denpasar 80232 \\ Email: iaputucitradewi@gmail.com \\ gungdani@gmail.com
}

Program Studi Agribisnis, Fakultas Pertanian, Universitas Udayana

\section{Abstract \\ The Role of Marketing Mix Perception on the Purchasing Decision and the Product Loyalty to the Hatten Wines}

Hatten Wines is a local wine-based local alcoholic beverage product that is sought after by tourists visiting Bali. The decline in product sales turnover of Hatten Wines since 2008 lies behind this study. The purpose of the study was to identify the variables that determine the marketing mix decisions on the product purchases and loyalty toHatten Wines and their constituent indicators and determine the role of the marketing mix perceptions on the purchasing decisions and loyalty to the products of Hatten Wines. The study was conducted in Sanur, Kuta and Nusa Dua by distributing questionnaires to 100 foreign tourists. The data were analyzed based on the factor analysis with SPSS 19 program. The findings showed that the marketing mix variables that determine the purchasing decision and the loyalty to the products of Hatten Wines consist of four variables: product, price, promotion, place and distribution. The product variables are formed from five indicators: brand, flavor, packaging, aroma, and product variety. Price variables are formed from three indicators, namely affordability, price conformity with benefits, and price competitiveness. Promotional variables formed from four indicators of promotional services, promotional media, promotional quality, and promotional quantity. Place and distribution variables are made up of three indicators: place of sale, product availability, and ease of access. The role of the marketing mix perceptions on the purchasing decisions and the product loyalty to Hatten Wines can be explained by the variance value of $60,946 \%$, the remaining $39,054 \%$ is influenced by other variables that are not incorporated into the model. Improved marketing mix quality is needed to improve the competitiveness of the products of Hatten Wines from those of imported products.

Keywords: marketing mix, purchasing decisions, loyalty

\section{Pendahuluan}

\subsection{Latar Belakang}

Pulau Bali sebagai salah satu destinasi wisatawan baik domestik maupun mancanegara, sangat bergantung terhadap produk pangan hasil pertanian salah satunya terkait dengan penyediaan produk minuman yaitu wine bagi wisatawan, 
namun ketergantungan terhadap produk minuman impor sangat tinggi. Salah satu produk wine lokal yang juga dibuat dari buah anggur lokal adalah Hatten Wines, namun sejak 2008 selalu mengalami penurunan volume penjualan. Penurunan volume penjualan tersebut dapat diakibatkan karena perubahan perilaku konsumen yang berimplikasi dalam pengembangan strategi pemasaran dimana terkait dengan bauran pemasaran, yaitu produk (product), harga (price), promosi (promotion), serta tempat dan distribusi (place and distribution). Konsumen memiliki persepsi yang beragam dalam kaitannya dengan keputusan pembelian. Persepsi konsumen yang positif terhadap aspek-aspek bauran pemasaran, dapat menjamin kepuasan dalam menggunakan produk tersebut sehingga akan terus melakukan pembelian kembali, dan kemudian memicu timbulnya loyalitas. Maka penelitian tentang peranan persepsi bauran pemasaran terhadap keputusan pembelian dan loyalitas produk Hatten Wines menjadi sangat penting dalam rangka merumuskan strategi pemasaran untuk meningkatkan peran produk Hatten Wines di pasar wisatawan, khususnya mancanegara.

\subsection{Rumusan Masalah}

Berdasarkan uraian latar belakang masalah tersebut, maka dapat dirumuskan permasalahan sebagai berikut:

1. Apa saja variabel-variabel bauran pemasaran yang menentukan keputusan pembelian dan loyalitas produk Hatten Wines beserta indikator-indikator pembentuknya?

2. Bagaimana peranan persepsi bauran pemasaran terhadap keputusan pembelian dan loyalitas produk Hatten Wines?

\subsection{Tujuan Penelitian}

Berdasarkan latar belakang yang sudah dijelaskan, maka tujuan yang ingin dicapai dari penelitian ini yaitu:

1. Mengidentifikasi variabel-variabel bauran pemasaran yang menentukan keputusan pembelian dan loyalitas produk Hatten Wines beserta indikatorindikator pembentuknya.

2. Mengetahui peranan persepsi bauran pemasaran terhadap keputusan pembelian dan loyalitas produk Hatten Wines.

\section{Metode Penelitian}

\subsection{Lokasi dan Waktu Penelitian}

Penelitian ini dilakukan di Sanur, Kuta dan Nusa Dua. Pemilihan lokasi dilakukan secara sengaja (purposive). Penelitian dilaksanakan bulan Januari s.d Februari 2017. 


\subsection{Data dan Metode Pengumpulan}

\subsubsection{Jenis dan sumber data}

Jenis data yang digunakan dalam penelitian ini adalah data kualitatif (gambaran umum PT Hatten Bali dan produk Hatten Wines) dan data kuantitatif (hasil kuesioner). Data primer diperoleh dari responden melalui kuesioner. Data sekunder diperoleh dari buku, website, data dari PT Hatten Bali, dan hasil penelitian terdahulu sebagai referensi.

\subsubsection{Metode pengumpulan data}

Pengumpulan data dilakukan melalui metode observasi, wawancara, angket, dan studi kepustakaan.

\subsection{Penentuan Sampel Penelitian}

Pengambilan sampel berdasarkan metode purposive sampling. Sampel yang akan diteliti adalah wisatawan mancanegara yang pernah mengkonsumsi Hatten Wines. Penelitian menggunakan 100 responden mengikuti syarat analisis faktor. Penyebaran pengambilan sampel dilakukan secara proporsional pada tiga lokasi penelitian, yaitu 33,33 persen, maka jumlah sampel pada masing-masing lokasi penelitian adalah sebagai berikut: 33 sampel di Nusa Dua, 33 sampel di Kuta, dan 34 sampel di Sanur.

\subsection{Variabel Penelitian dan Pengukuran}

Variabel penelitian beserta indikator dijelaskan dalam tabel 1.

Tabel 1.

Variabel Penelitian dan Indikator

\begin{tabular}{ccc}
\hline No. & Variabel & Indikator (Persepsi) \\
\hline & & Merek \\
1. & Produk & Citarasa \\
& & Kemasan \\
& Aroma \\
& & Variasi produk \\
\hline 2. & Harga & Keterjangkauan harga \\
& & Kesesuaian harga dengan manfaat \\
& & Daya saing harga \\
\hline 3. & & Tempat penjualan \\
& & Ketersediaan produk \\
& & Kemudahan akses \\
\hline 4. & Promosi & Layanan promosi \\
& & Media promosi \\
& & Kualitas promosi \\
& & Kuantitas promosi \\
\hline & & Pembelian kembali \\
& & Mempromosikan \\
& & Merekomendasikan \\
\hline
\end{tabular}




\subsection{Metode Analisis Data}

\subsubsection{Pengukuran skala likert}

Indikator-indikator yang diukur mempunyai lima tingkat preferensi jawaban dengan rincian sebagai berikut: sangat tidak baik/sangat tidak setuju (skor 1), tidak baik/tidak setuju (skor 2), ragu-ragu (skor 3), baik/setuju (skor 4), sangat baik/sangat setuju (skor 5). Persepsi responden terhadap bauran pemasaran, serta keputusan pembelian dan loyalitas diuraikan secara kuantitatif menggunakan interval kelas dengan mengintegrasikan rata-rata skor menurut kategori penilaiannya. Kategori ini dapat dilihat pada tabel 2 .

Tabel 2.

Kategori Skor Persepsi Konsumen Produk Hatten Wines

\begin{tabular}{ccc}
\hline Skor & Interval Skor & Kategori \\
\hline 1 & $1 \mathrm{~s} / \mathrm{d}<1,8$ & Sangat Tidak Baik/Sangat Rendah \\
2 & $1,8 \mathrm{~s} / \mathrm{d}<2,6$ & Tidak Baik/Rendah \\
3 & $2,6 \mathrm{~s} / \mathrm{d}<3,4$ & Cukup \\
4 & $3,4 \mathrm{~s} / \mathrm{d}<4,2$ & Baik/Tinggi \\
5 & $4,2 \mathrm{~s} / \mathrm{d} 5$ & Sangat Baik/Sangat Tinggi \\
\hline
\end{tabular}

Sumber: Usman, dalam Henrques (2014)

\subsubsection{Analisis faktor}

Data dari kuesioner diolah dengan analisis faktor menggunakan aplikasi SPSS 19, namun harus diuji normalitas dengan uji Kolmogorov-Smirnov.

\section{Hasil dan Pembahasan}

\subsection{Gambaran Umum Perusahaan}

PT Hatten Bali merupakan salah satu produsen wine yang berlokasi di Bali. Pertama kali didirikan pada tahun 1994 oleh Ida Bagus Rai Budarsa. Perkebunan PT Hatten Bali terletak di Kabupaten Buleleng. Pabrik dan kantor pusat berlokasi di Sanur. Hatten Wines terdiri dari beberapa produk antara lain Rose, Aga White, Aga Red, Alexandria, Tunjung, Jepun, dan Pino de Bali, dan merek lain yakni Two Islands, Dragonfly Moscato, dan Dewi Sri. Varietas yang ditanam di Bali adalah Probolinggo Biru lokal, anggur hitam lokal Alphonse-Lavallée, French Table Grapes, dan anggur putih lokal Belgia.

\subsection{Karakteristik Responden}

\subsubsection{Karakteristik berdasarkan kewarganegaraan}

Sebagian besar responden berkewarganegaraan Australia (20\%). Diikuti oleh Belanda (10\%), Norwegia (10\%), Perancis (7\%), Amerika Serikat (6\%), Selandia Baru (6\%), Kanada (5\%), Belgia (4\%), Inggris (4\%), Italia (4\%), Jerman (4\%), Polandia (4\%), Austria (3\%), Swiss (3\%), Denmark (2\%), Finlandia (2\%), Hongkong $(2 \%)$, Singapura (2\%), dan Swedia (2\%). 


\subsubsection{Karakteristik berdasarkan tempat tinggal}

Sebagian besar responden tinggal di hotel berbintang (57\%). Diikuti oleh villa (15\%), penginapan (14\%), hotel non-bintang (11\%), dan lainnya (3\%).

\subsubsection{Karakteristik berdasarkan jenis kelamin}

Sebagian besar persentase responden berjenis kelamin perempuan sebesar 55\% sedangkan laki-laki $45 \%$.

\subsubsection{Karakteristik berdasarkan usia}

Sebagian besar responden berusia 26-55 tahun (48\%). Diikuti oleh responden yang berusia 17-25 tahun (45\%), lebih dari 56 tahun (7\%), dan tidak ada responden yang berusia kurang dari 17 tahun.

\subsubsection{Karakteristik berdasarkan kedatangan ke Bali}

Sebagian besar responden datang ke Bali bersama teman (38\%). Diikuti oleh responden yang datang bersama kelompok (29\%), keluarga (27\%), dan sendiri (6\%).

\subsubsection{Karakteristik berdasarkan pekerjaan}

Sebagian besar responden adalah pelajar/mahasiswa (35\%). Diikuti oleh pengusaha $(15 \%)$, profesional/manajer/eksekutif $(13 \%)$, pegawai privat $(12 \%)$, ibu rumah tangga $(10 \%)$, pegawai pemerintahan $(7 \%)$, pensiunan $(5 \%)$, lainnya $(3 \%)$, dan tidak ada responden yang bekerja sebagai polisi/tentara.

\subsubsection{Karakteristik berdasarkan periode kunjungan}

Sebagian besar responden berkunjung ke Bali lebih dari 5 kali (31\%). Diikuti oleh kunjungan kedua kali (18\%), pertama kali (14\%), keempat kali (14\%), kelima kali (10\%), dan ketiga kali (13\%).

\subsection{Hasil Uji Instrumen Penelitian}

\subsubsection{Uji normalitas}

Uji normalitas menggunakan uji Kolmogorov-Smirnov. Seluruh indikator memiliki nilai Sig. > 0,05 berarti memenuhi asumsi normalitas.

\subsubsection{Uji validitas}

Seluruh item pertanyaan mempunyai nilai $r$ hitung $>$ dari $r$ tabel artinya valid dan dapat digunakan dalam penelitian.

\subsubsection{Uji reliabilitas}

Seluruh item pertanyaan penelitian memiliki nilai koefisien Cronbach's Alpha $>0,60$ artinya reliabel dan dapat digunakan dalam penelitian. 


\subsection{Persepsi Konsumen terhadap Bauran Pemasaran Hatten Wines}

\subsubsection{Persepsi konsumen terhadap produk Hatten Wines}

Responden memiliki persepsi yang baik pada komponen produk yang terdiri dari lima indikator yaitu merek, citarasa, kemasan, aroma, dan variasi produk dengan skor 4,1 artinya responden menyukai komponen produk Hatten Wines tersebut.

\subsubsection{Persepsi konsumen terhadap harga produk Hatten Wines}

Responden memiliki persepsi yang baik pada komponen harga yang terdiri dari tiga indikator yaitu keterjangkauan harga, kesesuaian harga dengan manfaat, dan daya saing harga dengan skor 3,9 artinya responden menyukai komponen harga produk Hatten Wines tersebut.

\subsubsection{Persepsi konsumen terhadap promosi produk Hatten Wines}

Responden memiliki persepsi yang baik pada komponen promosi yang terdiri dari empat indikator yaitu layanan promosi, media promosi, kualitas promosi, dan kuantitas promosi dengan skor 4,0 artinya responden menyukai komponen promosi produk Hatten Wines tersebut.

\subsubsection{Persepsi konsumen terhadap tempat dan distribusi produk Hatten Wines}

Responden memiliki persepsi yang baik pada komponen tempat dan distribusi yang terdiri dari tiga indikator yaitu tempat penjualan, ketersediaan produk, dan kemudahan akses dengan skor 3,7 artinya responden menyukai komponen tempat dan distribusi produk Hatten Wines tersebut.

\subsubsection{Keputusan pembelian dan loyalitas konsumen terhadap produk Hatten Wines}

Keputusan pembelian dan loyalitas termasuk dalam kategori tinggi dengan skor 3,9, dimana masing-masing indikator yaitu pembelian kembali, mempromosikan, dan merekomendasikan memiliki skor yang berada pada kategori tinggi juga. Hal ini berarti bahwa responden memiliki kecenderungan yang tinggi dalam mengambil keputusan untuk membeli dan loyal terhadap produk Hatten Wines. Sebagian besar responden menyatakan akan melakukan pembelian kembali (59\%), diikuti oleh mempromosikan (26\%), dan merekomendasikan (15\%). Hsiung (2011) mengklasifikasikan loyalitas konsumen ke dalam tiga kategori yaitu pembelian kembali (rebuy), mempromosikan (promote) dan merekomendasikan (recommend) produk. Hasil penelitian menunjukkan bahwa tahapan tertinggi loyalitas konsumen terhadap produk Hatten Wines adalah pada tahap awal yaitu melakukan pembelian ulang (rebuy). 


\subsection{Variabel-variabel Bauran Pemasaran yang Menentukan Keputusan Pembelian dan Loyalitas Produk Hatten Wines}

\subsubsection{Uji penentuan variabel}

Nilai KMO MSA 0,806 0,5 dan Sig. (p) 0,000 < 0,05 serta nilai MSA per indikator seluruhnya mempunyai nilai $>0,5$ dapat disimpulkan bahwa seluruh indikator layak untuk dianalisis lebih lanjut.

\subsubsection{Nilai eigenvalues sebagai pembentuk variabel}

Berdasarkan hasil penelitian telah terbentuk empat variabel (karena memiliki nilai initial eigenvalues total $\geq 1$ ). Variasi nilai eigenvalues masing-masing varibel yang terbentuk yaitu variabel 1 memiliki nilai initial eigenvalues total sebesar 4,816, variabel 2 sebesar 1,645, variabel 3 sebesar 1,472, dan variabel 4 sebesar 1,209. Hasil penelitian menunjukkan bahwa variabel 1 merupakan penentu terbesar di antara keempat variabel bauran pemasaran dengan persentase varians sebesar $32,110 \%$, diikuti oleh variabel $2(10,968 \%)$, variabel $3(9,810 \%)$, dan variabel 4 $(8,058 \%)$. Berdasarkan nilai total varians dapat dilihat bahwa nilai total varians adalah 60,946\%, yang artinya variabel 1, 2, 3 dan 4 dapat menjelaskan peranannya dalam menentukan keputusan pembelian dan loyalitas produk Hatten Wines, sedangkan sisanya 39,054\% dipengaruhi oleh variabel lain yang tidak dimasukkan dalam model.

\subsubsection{Peranan masing-masing indikator dalam menentukan variabel}

Angka pembatas agar sebuah indikator dapat secara nyata termasuk kedalam sebuah variabel adalah 0,5 (Santoso, 2015:85). Berdasarkan hasil rotasi semua indikator memiliki nilai factor loading lebih dari 0,5 yang menunjukkan bahwa seluruh indikator memiliki hubungan yang kuat dengan variabel-variabel yang terbentuk. Variabel 1 dinamakan variabel produk yang terbentuk dari 5 indikator, variabel 2 dinamakan variabel harga yang terbentuk dari 3 indikator, variabel 3 dinamakan variabel promosi yang terbentuk dari 4 indikator, kemudian variabel 4 dinamakan variabel tempat dan distribusi yang terbentuk dari 3 indikator. Berdasarkan penjelasan sebelumnya maka dapat dibuat model seperti Gambar 1. 


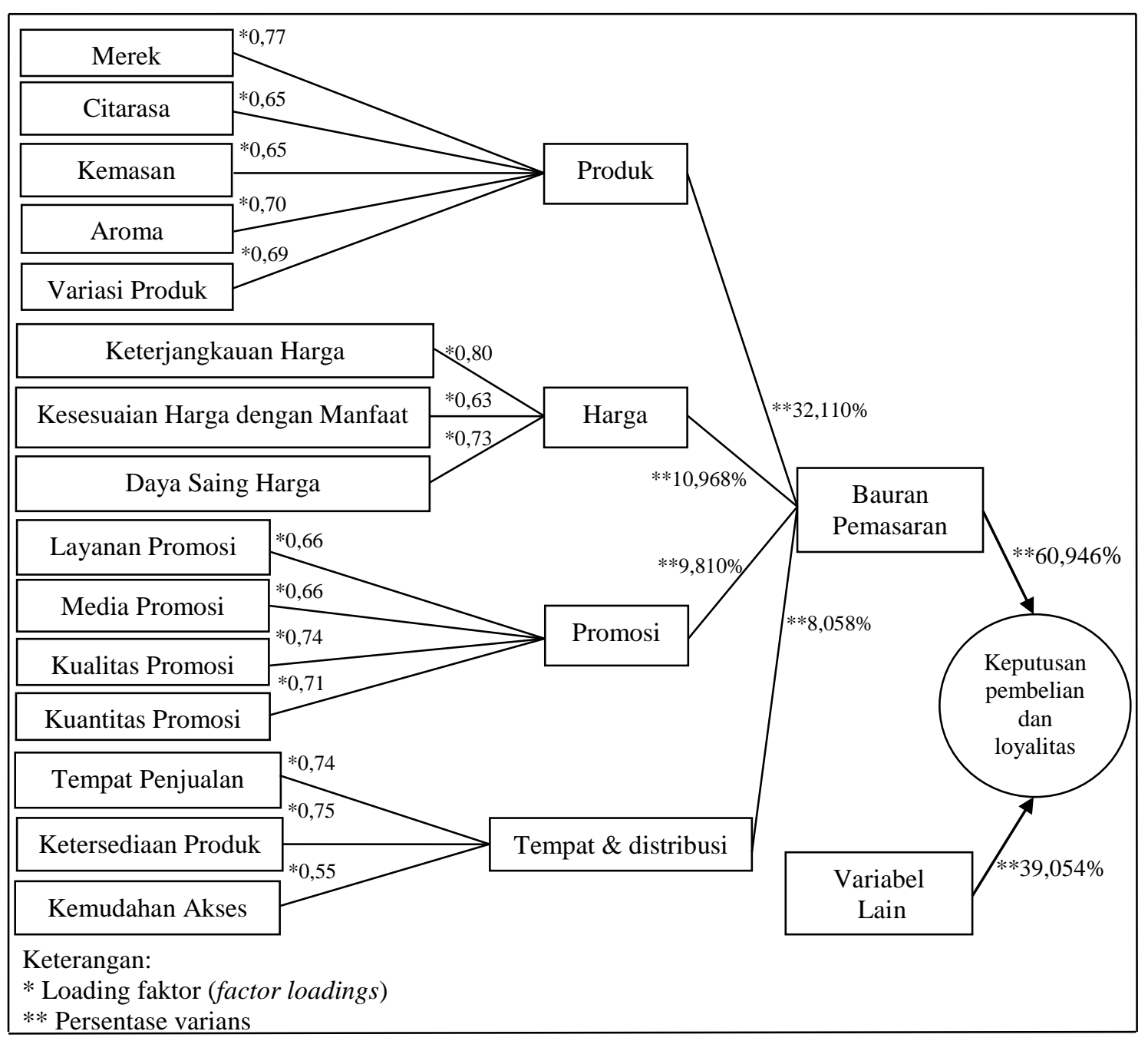

Gambar 1. Peranan Persepsi Bauran Pemasaran terhadap Keputusan Pembelian dan Loyalitas Produk Hatten Wines

Berdasarkan Gambar 1 dapat dilihat bahwa dari keempat variabel yang terbentuk, variabel yang mempunyai tingkat peranan yang paling besar adalah produk $(32,110 \%)$, diikuti oleh harga $(10,968 \%)$, promosi $(9,810 \%)$, serta tempat dan distribusi $(8,058 \%)$. Peranan total variabel-variabel tersebut ditunjukkan melalui nilai total varians sebesar $60,946 \%$, yang artinya bahwa variabel-variabel persepsi bauran pemasaran yang menentukan keputusan pembelian dan loyalitas produk Hatten Wines dapat dijelaskan sebesar 60,946\% oleh variabel produk, variabel harga, variabel promosi, serta variabel tempat dan distribusi. Sisanya dipengaruhi oleh variabel lain yang belum dimasukkan dalam model sebesar 39,054\%. 


\section{Simpulan dan Saran}

\subsection{Simpulan}

Berdasarkan hasil penelitian dan pembahasan yang telah diuraikan, maka dapat ditarik kesimpulan sebagai berikut:

1. Variabel-variabel bauran pemasaran yang menentukan keputusan pembelian dan loyalitas produk Hatten Wines terdiri dari empat variabel yaitu produk, harga, promosi, serta tempat dan distribusi. Variabel produk terbentuk dari lima indikator yaitu merek, citarasa, kemasan, aroma, dan variasi produk. Variabel harga terbentuk dari tiga indikator yaitu keterjangkauan harga, kesesuaian harga dengan manfaat, dan daya saing harga. Variabel promosi terbentuk dari empat indikator yaitu layanan promosi, media promosi, kualitas promosi, dan kuantitas promosi. Variabel tempat dan distribusi terbentuk dari tiga indikator yaitu tempat penjualan, ketersediaan produk, dan kemudahan akses.

2. Persepsi tentang bauran pemasaran memiliki peranan yang sangat penting terhadap keputusan pembelian dan loyalitas produk Hatten Wines. Peranan tersebut dapat dijelaskan oleh variabel produk, variabel harga, variabel promosi, serta variabel tempat dan distribusi sebesar 60,946\%. Sisanya dipengaruhi oleh variabel lain yang tidak dimasukkan dalam model sebesar 39,054\%.

\subsection{Saran}

Berdasarkan kesimpulan dari hasil penelitian, maka diajukan beberapa saran sebagai berikut:

1. PT Hatten Bali sebaiknya meningkatkan variabel-variabel bauran pemasaran yaitu variabel produk, variabel harga, variabel promosi, serta variabel tempat dan distribusi karena sesuai perhitungan telah terbukti dapat menentukan keputusan pembelian dan loyalitas konsumen terhadap produk Hatten Wines. Dilihat dari nilai per indikatornya, PT Hatten Bali dapat lebih memfokuskan dalam hal meningkatkan merek, keterjangkauan harga, dan tempat penjualan, karena ketiga indikator ini memiliki peranan terbesar diantara indikatorindikator lain.

2. Penelitian ini hanya mampu menjelaskan peranan persepsi bauran pemasaran terhadap keputusan pembelian dan loyalitas produk Hatten Wines sebesar $60,946 \%$. Hal ini diharapkan dapat dijadikan peluang bagi peneliti lain untuk meneliti 39,054\% sisanya yang tidak dapat dijelaskan dalam penelitian ini.

\section{Ucapan Terimakasih}

Penulis menyampaikan terimakasih kepada seluruh pihak yang telah membantu dalam pelaksanaan penelitian sehingga karya ilmiah ini dapat dipublikasikan dalam e-jurnal. 


\section{Daftar Pustaka}

Ariyanti, F. 2016. RI Jadi Pasar Empuk Impor Wine di ASEAN. http://bisnis.liputan6.com/read/2450345/ri-jadi-pasar-empuk-impor-wine-diasean. (Diakses pada tanggal 3 November 2016).

Fadhilah, A. P. 2013. Analisis Pengaruh Produk, Harga, Promosi dan Saluran Distribusi Terhadap Keputusan Pembelian Konsumen (Studi Pada Outlet The Body Shop Java Mall Semarang). Skripsi. Semarang: Fakultas Ekonomika dan Bisnis, Universitas Diponegoro. http://eprints.undip.ac.id/43099/1/FADHILAH.pdf. (Diakses pada tanggal 3 November 2016).

Henrques, F. D. C. 2014. Pengaruh Program Pendidikan dan Pelatihan Terhadap Kinerja Pegawai (Studi Kasus pada Instituto Nacional da administração Publica Timor Leste). Jurnal. Denpasar: Program Studi Ilmu Administrasi Negara, Fakultas Ilmu Sosial dan Politik, Universitas Udayana. http://an.fisip.unud.ac.id/wp-content/uploads/2014/05/Flavia-Da-CostaHenrques-1021205010.rtf (Diakses pada tanggal 21 April 2017).

Hsiung, L. C. 2011. A Study on the Relationships Between the Brand Image and Customer Satisfaction in Catering Businesses, African Journal of Business Management Vol. $\quad 5 \quad$ (7732-7739). http://www.academicjournals.org/article/article1380705690_Lin.pdf (Diakses pada tanggal 31 Maret 2017).

Masuki. 2012. Bali Dipenuhi Produk Wine Impor. http://bali.antaranews.com/berita/27602/bali-dipenuhi-produk-wine-impor.

(Diakses pada tanggal 3 November 2016)

Santoso, S. 2015. Menguasai Statistik Multivariat. PT Elex Media Komputindo: Jakarta.

Sari, Y. D. 2013. Analisis Faktor-Faktor Yang Mempengaruhi Keputusan Konsumen dalam Membeli Produk Industri Garment. Skripsi. Denpasar: Fakultas Ekonomi Universitas Udayana. http://ojs.unud.ac.id/index.php/Manajemen/article/download/2127/3317. 2013 (Diakses pada tanggal 19 Februari 2017)

Setiadi, N. J. 2010. Perilaku Konsumen: Perspektif Kontemporer pada Motif, Tujuan, dan Keinginan Konsumen. Kencana: Jakarta.

Sugiyono. 2010. Metode Penelitian Kuantitatif Kualitatif dan R\&D. CV Alfabeta: Bandung.

Suryawardani, I G. A. O. 2014. Tourism Leakage From The Accommodation in Bali. Ph.D Dissertation. Denpasar: Program Studi Doktor Pariwisata, Universitas Udayana. 